\title{
Energy Technology Innovation Systems in a Transnational Perspective: Small States, Public Ownership and Diverging Policy Rationales
}

Piret Tõnurist ${ }^{1}$

\section{Aim and scope of the thesis}

Climate change has become a formidable challenge for energy systems. To answer this challenge governments are increasingly engaged with the formation and direction of energy innovation systems towards sustainable energy transitions. This, however, is marked with high levels of uncertainty, complexity, interdependence and inertia. First, because of the technological challenges, scarce resources and high sunk costs of investments; second, because of a high level of lobbying by advocacy coalitions; and lastly, because the international regulatory systems governing climate change are continuously changing. Governments are called on to foresee changes on all these multiple levels and signal within energy innovation systems the direction of investment, while using various policy instruments. This puts high demands on the capacities, organization and integrity of public-policy bodies, which are not always met. Thus, there are significant limits to the capacity to project and govern transitions in the making. Furthermore, policy rationales connected to the energy sector are not always clear-cut and one-dimensional. First, from the global-climate-crisis discourse an agenda has emerged calling for expedient change and decarbonization ("technological fix") of the energy sector; second, there are economic interests connected to the development of energy technologies (the so-called "green growth" agenda); third, there has been a longterm debate surrounding energy security ("electric vulnerability") in Europe and in the world, with calls for more investment in and internationalization of energy systems not to be dependent on single energy-supply routes nor energy sources.

1 Overview of the thesis: PhD thesis awarded as the "Mzia Mikeladze Thessis Award" at the $25^{\text {th }}$ NISPAcee Annual Conference held in Kazan, Republic of Tatarstan, Russian Federation, 18-20 May 2017. 
Consequently, policy makers have to manoeuvre very complex minefields of interests when dealing with the energy sector.

As such, this thesis looks into the interaction of public policy and underlying politics with technological change in the energy sector. What we suppose is that policy change co-evolves with both technology and institutions (Borrás and Edler 2015). Because the challenges outlined above are intrinsically connected to technological development, it would be easy to fall into the trap of linear policymaking, concentrating on the supply of new energy technologies. This, however, is shown not to work in the energy sector (Suurs and Hekkert 2009). Hence, more complex, systemic solutions are called for. This thesis tackles these problems from different angles developing an analytical approach that is technology-specific, accounts for institutional differences, transnational linkages and geography of change (namely the role of state size in technological change processes) in energy technology innovation systems. For this the author puts together recent developments in innovation systems (IS) literature - specifically technological innovation systems (TIS) -, arguments from economic geography (the relative size and proximity of states) and research done under the global-value-chain (GVC) stream. TIS, among other innovation-system perspectives, was chosen due to its focus on technology specific effects, but also because the unit of analysis is on the network level in most empirical accounts, which will help to integrate the GVC perspective into the analytical framework.

The main arguments of the thesis are developed in four original articles. In all articles the author of the thesis has been the sole or lead author (I, II, III, IV) - see Table 1 below. In the first article, the author of the thesis pursues the issue of state size in times of globalization and argues that objective measures of space have become obsolete during times of increasing interconnectedness and economic liberalization (I). The article reaches the conclusion that "size" is dependent on three factors: economic structure, development level and core-periphery relationships. In terms of technological development this can be connected to the concept of "proximity" (Boschma 2005) that has recently been applied to innovation systems research (Lundquist and Trippl 2013). The thesis outlines the problems and possibilities for small states in the context of increased internationalization of technology (I, 14-15). Furthermore, the article introduces the importance of global production networks (GPN) as important parts of dispersed knowledge production and the influence of multi-national companies (MNC) on the economic power of small states. Thus, the article builds the backbone for the reasoning to look at states' innovative capabilities in a transnational perspective. 


\section{Table 1}

Articles in the cumulative thesis

\section{List of publications}

\begin{tabular}{|ll|}
\hline I & $\begin{array}{l}\text { Tõnurist, P. 2010. What is a "Small State" in Globalizing Economy? } \\
\text { Halduskultuur - Administrative Culture 11(1), 8-29. }\end{array}$ \\
\hline II & $\begin{array}{l}\text { Tõnurist, P. 2015. "Framework for Analysing the Role of State Owned } \\
\text { Enterprises in Innovation Policy Management: The Case of Energy } \\
\text { Technologies and Eesti Energia." Technovation 38, 1-14. }\end{array}$ \\
\hline III & $\begin{array}{l}\text { Tõnurist, P. and E. Karo. 2016. "State Owned Enterprises as Instruments } \\
\text { of Innovation Policy." Annals of Public and Cooperative Economics 87(4), } \\
\text { 623-648, 10.1111/apce.12126. }\end{array}$ \\
\hline IV & $\begin{array}{l}\text { Tõnurist, P., D. den Besten, P. Vandeven, X. Yu and D. Paplaityte. 2015. } \\
\text { "Market Liberalization and Innovation in the Energy Sector: The Case of } \\
\text { Belgium and the Netherlands." Halduskultuur - Administrative Culture 16(2), } \\
\text { 83-116. }\end{array}$ \\
\hline Appendix & $\begin{array}{l}\text { Tõnurist, P. and K. Valdmaa. 2013. "From Global Discourse to National } \\
\text { Policy Effects: Impact of Climate Discourse on National Scientific Networks } \\
\text { in Energy Technologies." Revised version of the paper presented at the 6" } \\
\text { Annual Conference of the Academy of Innovation and Entrepreneurship, } \\
\text { Innovation and Entrepreneurship for Inclusive and Sustainable Development, } \\
\text { Oxford, UK, 29-30 August 2013. (5.2) }\end{array}$ \\
\hline V &
\end{tabular}

Source: Author.

In the second single-authored article (II), the author looks at the role of state-owned enterprises in energy innovation systems in a small-state context. The complex nature of governing energy innovation systems and the conflicting rationales influencing these systems are outlined through the example of Eesti Energia, a state-owned energy company in Estonia primarily engaged in nonrenewables. The article shows how the innovation policy agenda can compound with the environmental and energy-security agenda and even fiscal policy interests in the context of state-owned enterprises. Innovation systems in the energy system are, thus, confronted with immense policy legacies; even more so, as most energy sectors have been and are still characterized by public ownership. Nonetheless, in the liberalized market economy even state-owned enterprises (SOEs) move in GVCs, and this, as was shown in the case of Eesti Energia, can be a way for companies to deliberately decrease the control of national governments (II, 10). The case study, in the context of the current thesis, shows the importance of both accounting for national institutional contexts and also transnational value chains in describing energy technology development.

Two articles in the main body of the thesis were co-authored: one with Dr. Erkki Karo on the role of SOEs in the oil and gas sector (III) and the other with colleagues from Belgium and the Netherlands, who helped collect the data to analyze the effect of market-liberalization reforms on incumbent electricity producers 
in Belgium and the Netherlands (IV). The former outlines the role of state-owned enterprises globally in the energy sector and describes their potential as innovation policy instruments in varied policy contexts (III). Furthermore, different policy rationales influencing SOEs in the energy sector (and beyond) and the importance of different institutional environments for energy technology innovation systems are outlined. Moreover, the article makes a case for the influence of diverging political interests on SOEs' innovation activities in the energy sector through case studies of different government-controlled oil companies in the world. The second coauthored article (IV) outlines the possible impact of applying traditional, marketbased policies in the energy sector and not discriminating between technologies. Thus, the article uses the cases of the Belgian and Dutch energy sectors to show the need for technology-specific approaches and, thus, the potential role of technology innovation systems analysis.

The Appendix of the thesis contains a paper co-authored with Kaija Valdmaa on the effect of the global climate-change discourse - the so-called sustainability agenda - on domestic energy-R\&D networks $(\mathbf{V})$. This article strengthens the claims made in article IV, showing that supporting innovation indiscriminately is not enough to induce change in energy technology innovation systems. The paper outlines the dangers of linear, technology-fix based innovation policy discourse through the example of science and industry linkages within the energy sectors. The article shows that if more precise, technology-specific approaches to innovation policy are not taken, it can stall sustainability transitions in the energy sector.

Put together, the five original works the thesis is composed of, outline the need for a technology-specific energy innovation systems analysis that accounts for both space - national and transnational effects - and various policy agendas in the complex policy legacies within the energy sectors. Consequently, in the following introduction of this thesis the author tries to go beyond the elements of energy innovation systems (networks, hierarchies, markets described in the articles) and to outline a more comprehensive picture of energy technology innovation systems that accounts for not only technological momentum, but also space-specific tendencies and power relations (exemplified by small-states challenges in internationalized technology development processes). There is a lot of room in innovation-systems literature to conceptually identify the role of transnational linkages, learning processes, global value chains and relationships with the wider international context. Innovation-systems literature, while seemingly all-encompassing, seems to neglect many of the former dimensions. As such, one of the main critiques of the innovation-systems approach is the static, mechanical and descriptive focus of analysis and the disproportionate focus on science and technology (S\&T), rather than the loci of innovation (Dodgson et al. 2011). Thus, for example, innovation-systems analyses tend to marginalize the market (inter- and intra-firm relations) and focus more on the non-market institutional dimension of innovation (Bleda and Del Rio 2013). As policies and funding of research and development (R\&D) are increas- 
ingly moving to supra-national levels (I; Tõnurist and Kattel 2016), innovation systems should also be analyzed on supranational levels. The TIS approach adds to the debate by stressing the need to combine factors that are intrinsic to technologies with contextual elements to create the conditions for technological development and its adoption (Bento and Fontes 2015). Integrating the global-value-chain approach with the technology innovation systems helps to more specifically analyze backward and forward linkages between actors (also on the firm level) in GVCs and understand how these affect learning and innovation.

The following research questions are addressed in the thesis:

(1) What are the main policy rationales governing the energy sector and how do these affect innovation and technological development in energy innovation systems?

(2) Which components of technology innovation systems should be analyzed to respond to challenges the energy sector is currently facing? What are the conceptual weaknesses in theory that should be addressed to reach a more realistic depiction of innovation processes in multiscalar energy innovation systems?

(3) What role does geography and state size play in transnational energy innovation systems? How can transnational linkages in energy innovation systems be studied? What could be the potential role of small states in transnational energy innovation systems?

(4) What is the potential role of state-owned enterprises in transnational energy innovation systems?

The introductory section of the thesis is developed as follows. First a short methodological overview of the thesis is provided. This is preceded by the delineation of challenges in technology innovation systems in the context of the energy sector. We approach the subject through the lens of sustainability transitions in the energy sector and discuss the conflicting policy rationales governing energy innovation systems (covered also in articles II; III; IV and V). Specifically the technology innovation systems approach is used (which is also most applied in the context of energy technologies) to introduce a technology-based dynamic into the multiscalar, transnational energy innovation systems approach. The benefits and weaknesses of the TIS approach for such a purpose are outlined. Specifically, the effect of geography is separately brought out, and a new focus on global value chains in evaluating innovation systems is proposed. This discussion ends with outlining the role and difficulties of small states in transnational energy innovation systems. This is especially important due to the sheer size of the global sustainability challenge the world is facing: with the global nature of the problem, large-scale, international technological development projects and the influence of emerging economies on energy demand, the role of small states in energy innovation systems seems to be 
almost insignificant. However, Mowery et al. (2010) argue that what is needed for a sustainability transition in the energy sector is not a new "Manhattan project", but rather more learning and experimentation with different technologies. Small states with less complex structures may be apt spaces for entrepreneurial action that spurs on learning, technological diffusion and leap-frogging (Mazzucato and Perez 2015). In a separate section, where the author discusses the contributions of the thesis to the aforementioned debate, the missing role of state-owned enterprises in the energy sector is also discussed in the context of transnational TISs. The last section proposes new avenues for research.

\section{Methodology}

Methodologically this thesis is cross-disciplinary, including approaches from political science, management studies, governance studies, evolutionary and institutional economics and innovation studies. As it is a combination of independently written articles, the methods applied are divided between different sections of the thesis.

The theoretical analysis of the thesis in its underlying assumptions draws heavily upon evolutionary economic theory (Nelson and Winter 1982), institutional economics (Powell and DiMaggio 2012) and recent developments in economic geography applied to innovation systems analysis (Lundquist and Trippl 2013). At the same time, traditional management theories were systematically reviewed in several of the articles (e.g. II; III) to illustrate some of the gaps in conventional theoretical perspectives. All articles in the thesis also follow a public-policy narrative and, specifically, search for the role of the state in technological development.

In more theoretically heavy contributions - for example when defining the concept of the "size" of states (I) -, the thesis relies on cumulative theoretical review (using both theoretical and empirical studies as inputs). When identifying the main policy rationales of state-owned enterprises (III) and the characteristics of the global-climate-change discourse $(\mathbf{V})$, systematic theoretical reviews were carried out with combined citation searches and the snowball method.

In the empirical analysis we combined different methodologies for analyzing the case studies (II; III; IV; V). In most cases data was triangulated from different sources to increase the validity of the studies. In general, several data sources were found to minimize the risk from single data sources. In the case study of Eesti Energia (II) a combination of in-depth, semi-structured interviews and document analysis was applied. Looking at the developments of the oil sector (III), three different cases (Statoil, Norway; Petrobras, Brazil; and PDVSA, Venezuela) were selected based on a pre-analysis of different state-owned enterprises in the oil sector and the connected national policy context. Cases were selected due to their illustrative properties (as 'crucial cases' for the phenomenon under study; Eckstein 1992), and a comparative case study methodology was applied (Yin 2003). Similarly the 
analysis of the effects of energy market liberalization on innovation and the role of market structures in the cases of Belgium and the Netherlands (IV) adopts a comparative research design. The aforementioned case studies do not aspire to be representative for a larger population - they are used for "theory building" purposes only (Amaratunga and Baldry 2001). As such, through the cases, contextual factors surrounding the unit of analysis are identified. In the paper analyzing the effects of the climate discourse on scientific networks $(\mathbf{V})$, first, a basic discourse analysis was carried out to identify the broad narrative changes in the Estonian policy context, and, second, an integrated approach applying both quantitative (network analysis) and qualitative methods (documentation analysis, semi-structured interviews etc.) was applied to research the change in practise.

Together, the mixed methodological approach can be seen as a way to overcome the tragedy of "wicked" or even "super wicked" problems in innovation policymaking in the energy sector. Levin et al. (2012) define the aforementioned in the context of climate change by four key features: (1) time is running out; (2) the central authority, who is needed to address the problems, is weak or non-existent; (3) those who cause the problem seek to provide the solutions; and as a result, (4) policy responses discount the future irrationally, even if faced with catastrophic future impacts. When these features are combined - as is the case in the field of sustainability transitions in the energy sector and especially the climate crisis - traditional methodological approaches are not equipped to identify potential solutions (ibid.). We will show below that this is especially the case in innovation policy design. When investigating energy innovation systems, the goal is to concentrate on not only simple, static effects, but (positive and negative) feedback loops in the system dependent on complex policy legacies within the energy sector (Jordan and Matt 2014). This requires system thinking and reflexive learning - iterative and recursive approaches - not only from the policies involved, but also in methods applied to the study of energy innovation systems. Rather than "single shot analysis", social sciences in this context should identify the "connection of chains of contingencies that could shape the future" (Bernstein et al. 2000, 53). This is also the baseline for the following discussion on energy innovation systems and sustainability transitions and the development of the new analytical approach to study multiscalar, transnational energy technology innovation systems.

\section{Contribution of the thesis}

The thesis advanced the academic debate concerning energy innovation in a number of ways. First, the thesis highlighted the conflicting policy rationales sustainability, economic and security-related rationales - governing the energy sector. All of the above introduce their own logic to technological development in energy innovation systems. Second, the technology-innovation-systems perspective coupled with the global-value-chains discussion was used to build a 
new model of multiscalar, spatially-aware transnational technology innovation systems. By highlighting the main weaknesses of both approaches (lack of scale, geography, interaction between technological systems and energy politics in the case of TIS; and concentrating solely on firm-level effects and discounting the importance of the institutional setting in the case of GVCs) we hope to move to a more comprehensive and realistic depiction of innovation processes in energy innovation systems. As one of the important scale effects is also the size of states that influences the possibility to reap value/rents from energy innovation systems, also the case of small states was discussed in the afore-described model. In this way the argumentation takes a step further from the material presented in independently written articles. Nevertheless, the articles comprising this body of work also add specific value to the discussion above and beyond.

Paradoxically, the journey towards more technologically and spatially-aware innovation systems in the field of energy innovation systems started with a paper concerned with defining state size in a globalized economic setting (I). Through the discussion of the effects of globalization, open economies and GPN and MNCs, the relative size of states was outlined. While innovation systems were not mentioned explicitly in the paper, many of the underlying assumptions and the cited papers come from this perspective. The article led to the realization that there is a large gap in innovation systems analysis when it comes to juxtaposing one innovation system with another - seeing them in synergic, competing etc. relationships. The article coincided with the time when innovation scholars started to give more attention to the role of developing countries in innovation systems analysis. In the former, governance as a tool for system upgrading and building capacities was especially highlighted. Nevertheless, the interaction and interdependencies of various innovation systems - and also the transnational vehicle of such communications and learning - was still missing from the theoretical debate. In TIS this "vehicle" is technology and the networks and learning effects that converge around it. Consequently, the definition of relational "size" in global economies paved the way to the acknowledgement of technological momentum behind GPN/GVCs and the need to combine the aforementioned approaches with the innovation-systems perspective.

The following two contributions on state-owned enterprises in the energy sector (II; III) were innovative in their own right, as both helped to introduce a completely new topic to the analysis of public enterprises - namely their role in innovation policy management. As argued above, and in the contribution with Dr. Erkki Karo (III), governments still control large shares of the global energy sector, and many of the largest multinationals in the field are government-controlled businesses. Consequently, state-owned enterprises and subnational government investments are a large part of the energy sector. What makes these companies special is the fact that - as in the cases presented in the articles (II; III) - state-owned enterprises are basically given free reign over primary resource in the energy sector and, thus, also resource rents at the downstream of value chains. In many ways in non- 
renewable, resource-dependent sectors they seem to act counter-intuitively to societal sustainability goals adding to super wicked problems (II), although some do follow the innovation policy rationales (e.g. Statoil, Petrobras since the 1980s) and start to act as systemic innovation actors (III, 14). While most innovation activities in the energy sector are carried out - and thus, Schumpeterian rents are also created - outside of the energy-production section in associated industries, SOEs can have a strong technology-pull mechanism (employing innovation demand measures) to the development of energy technologies and whole value chains connected to them. Both articles (II; III) also show how and why public ownership may provide a better basis for long-term investment horizons.

Furthermore, SOEs are becoming MNCs in their own right, making investments abroad to take control of value chains, reduce transaction costs or, in the case of thin and narrow domestic research networks, buy in input from abroad, subsiding the domestic system (in the case of Eesti Energia, see II). Internationalization can be, of course, also caused by political or economic security objectives. This is especially true for SOEs in resource-based industries (ibid.). Consequently, similarly to MNCs, SOEs can become government conduits in global value chains in the multiscalar energy innovations systems described above - in search of Schumpeterian rents - in private networks and transnational relationships, where (small) states have little legitimacy or capabilities to manoeuvre. Thus, SOEs can facilitate learning and technology transfer in domestic and global value chains (see III). As unified units they may also have less coordination problems and transaction costs in participation in and with different GVCs. However, what sometimes is important is that there is a political mandate for such activities. Although SOEs can become independent innovators in their own right (as to a degree was the case with Eesti Energia; II), this does not mean that they will also pursue social sustainability goals in their innovative activities without stimuli. The largest state-owned enterprises in the world are largely among the fossil-fuel producers - oil and gas companies (III) - which means that their interests may run counter to sustainability rationales. Thus, the importance of power, politics and agency in energy innovation systems can be outlined by looking at stateowned enterprises in energy innovation systems. Consequently, studying stateowned enterprises in the multiscalar model of energy innovation systems may shed light on many of the issues we have outlined in the prior discussion.

The peculiarities of small-state energy innovation systems in the case of Estonia were also outlined in two contributions (II and V). In both cases some of the peculiarities of small-state innovation systems were highlighted: for example, in the case of Eesti Energia the fear of too strong and thin networks (II), and in the context of the climate discourse the copy-paste adoption of international standards and policy momentum was outlined (V). Furthermore, these papers show that contextual variables matter, and institutional context and interaction between different technological innovation systems can really influence value changes in the energy 
sector. The final two papers (IV; V) also serve as a cautionary tale in the context of the aforementioned debate of what happens if linear policy-making is allowed to run free even if sometimes the final goal - countering the climate crisis $(\mathbf{V})$ - is undeniably positive. Global discourses tend to generalize, as is the case with the climate-crisis narrative, and the technological nuances and the underlying assumptions of change seem to get lost. Thus, very broad-based narratives of sustainability solutions (V) or market failures (IV) seem to create almost coincidental and unintended impacts. This makes governing super wicked problems in energy innovation systems very difficult and, furthermore, engaging and directing energy-technology value chains almost impossible.

On the whole, the thesis highlights the need for more research on the coevolution of energy sectors, institutions, global value chains and technology.

\section{References}

Amaratunga, D. and D. Baldry. 2001. "Case Study Methodology as a Means of Theory Building: Performance Measurement in Facilities Management Organisations." Work Study 50(3), 95-105.

Bento, N. and M. Fontes. 2015. "Spatial Diffusion and the Formation of a Technological Innovation System in the Receiving Country: The Case of Wind Energy in Portugal." Environmental Innovation and Societal Transitions 15, 158-179.

Bernstein, S., R. N. Lebow, J. G. Stein and S. Weber. 2000. "God Gave Physics the Easy Problems: Adapting Social Science to an Unpredictable World." European Journal of International Relations 6(1), 43-76.

Bleda, M. and P. Del Rio. 2013. "The Market Failure and the Systemic Failure Rationales in Technological Innovation Systems." Research Policy 42(5), 1039-1052.

Borrás, S. and J. Edler. 2015. "The Governance of Change in Socio-Technical and Innovation Systems: Three Pillars for a Conceptual Framework." In S. Borrás and J. Edler (eds). The Governance of Socio-Technical Systems. Cheltenham, UK: Edward Elgar, 23-48.

Boschma, R. 2005. "Proximity and Innovation: A Critical Assessment." Regional Studies 39(1), 61-74.

Dodgson, M., A. Hughes, J. Foster and S. Metcalfe. 2011. "Systems Thinking, Market Failure, and the Development of Innovation Policy: The Case of Australia." Research Policy 40(9), 1145-1156. 
Eckstein, H. 1992 [1975]. “Case Study and Theory in Political Science.” In Eckstein, H. (ed.). Regarding Politics: Essays on Political Theory, Stability, and Change. Berkeley: University of California Press, 117-178.

Jordan, A. and E. Matt. 2014. "Designing Policies that Intentionally Stick: Policy Feedback in a Changing Climate." Policy Sciences 47(3), 227-247.

Levin, K., B. Cashore, S. Bernstein and G. Auld. 2012. "Overcoming the Tragedy of Super Wicked Problems: Constraining our Future Selves to Ameliorate Global Climate Change." Policy Sciences 45(2), 123-152.

Lundquist, K. J. and M. Trippl. 2013. "Distance, Proximity and Types of CrossBorder Innovation Systems: A Conceptual Analysis." Regional Studies 47(3), 450-460.

Mazzucato, M. and C. Perez 2015. "Innovation as Growth Policy: The Challenge for Europe." In J. Fagerberg, S. Laestadius and B. R. Martin. The Triple Challenge for Europe Economic Development, Climate Change and Governance. Oxford: Oxford University Press, 229-264.

Mowery, D.C., R. R. Nelson and B. R. Martin 2010. “Technology Policy and Global Warming: Why New Policy Models are Needed (Or Why Putting New Wine in Old Bottles Won't Work)." Research Policy 39, 1011-1023.

Nelson R. R. and S. G. Winter. 1982. An Evolutionary Theory of Economic Change. Cambridge: Harvard Business School Press.

Powell, W. W. and P. J. DiMaggio (eds). 2012. The New Institutionalism in Organizational Analysis. Chicago: University of Chicago Press.

Suurs, R. A. A. and M. P. Hekkert. 2009. "Competition between First and Second Generation Technologies: Lessons from the Formation of a Biofuels Innovation System in the Netherlands." Energy 34, 669-679.

Tõnurist, P. and R. Kattel. 2016. "Can Research, Development and Innovation Policies Cross Borders? The Case of Nordic-Baltic Region." Science and Public Policy, 1-13, 10.1093/scipol/scw066.

Yin R. K. 2003. Case study research; designs and method. Third edition. Thousand Oaks, CA: Sage Publications, Inc. 